\title{
Phytogeographic History of Taxodiaceae and Importance of Preserving Mixed Broad-leaved Deciduous/Evergreen Forest
}

\author{
Harufumi NISHIDA International Budo University, 841 Shinkan, Katsu-ura City, Chiba Pref. 299-52, Japan \\ Kazuhiko UEMURA National Science Museum, 3-23-1 Hyakunin-cho, Shinjuku-ku, Tokyo, 169 Japan
}

\begin{abstract}
During the Mesozoic Taxodiaceae were once widespread worldwide including the Southern Hemisphere, though they have been a northern hemispheric family since the Tertiary. During the Paleocene and Eocene of globally warm period, the Taxodiaceae were widespread in the Northern Hemisphere. Marked temperature decrease in the Late Eocene to earliest Oligocene resulted in the southward migration of northern deciduous broad-leaved forests to the mid-latitudes accompanying northern conifers. Subsequent climatic fluctuations since the Oligocene resulted in the restriction of distribution of many taxodiaceous genera in middle latitudes. The Taxodiaceae took refuge in the areas where mesic temperate to subtropical forests have existed continuously since the Cretaceous. To preserve the mesic to humid temperate forests that have kept rare stands of many taxodiaceous trees, without destroying their original diversity, is required.
\end{abstract}

Key Words: history /phytogeography / Taxodiaceae / mesic forest / mixed forest.

\section{GREENING OF EARTH AND GYMNOSPERM HISTORY}

In the history of green land plants exceeding 420 million years on this planet, angiosperms have dominated the earth surface in relatively short period. Before the rise of angiosperms estimated to be at the beginning of the Cretaceous some 140 million years ago (140 Ma), land surface had been covered mainly with free sporing plants (bryophytes and pteridophytes) and gymnosperms.

Gymnosperms appeared in the Late Devonian (370 Ma) as the first seed plant. With less than 800 living species of four major taxonomic groups (coniferophyte, cycadophyte, gnetophyte and ginkgophyte), present gymnosperms display only a small array of diversity in biosphere, though the living four groups are distantly related to each other as well as they are to angiosperms. However, paleobotanical evidence shows that gymnosperms had achieved their zenith of diversity during the Mesozoic, including more than twice as many extinct groups as the present four survivors. Angiosperms are believed to have derived from one of such diversified Mesozoic gymnosperms by the Early Cretaceous.

Throughout the Cretaceous various groups of gymnosperms had existed competing with the rapidly invading angiosperms. Many of these Mesozoic gymnosperms except the living four groups, however, could not survive the K/T (Cretaceous/Tertiary ) boundary event (65 Ma; e. g. Alvarez et al. 1980). 
In the early Tertiary, gymnosperms including many coniferophytes and some cycadophytes and ginkgophytes remained rigorously coexisting with angiosperms under the warm climate. These gymnopsperms came to reduce their diversity and distribution areas, mainly due to a climatic deterioration during the Late Eocene to Oligocene. However, some coniferophyte members, such as Abies, Picea and Pinus of the Pinaceae, had adapted in areas under colder or seasonally drier climates. Finally in the Quaternary, the remaining species were affected by Pleistocene periodical global glaciation, and the present relict distributional patterns were formed. This generalized scenario for the history of gymnosperms may strengthen the need of preserving entire stands of extant relict gymnosperms in terms of historical as well as genetical importance.

\section{TAXODIACEAE AND ALLIED FAMILIES}

The Taxodiaceae are a coniferophyte family relating to the Cupressaceae and Sciadopityaceae, and consisting of nine living genera (Cryptomeria, Glyptostrobus, Metasequoia, Sequoia, Sequoiadendron, Taxodium, Taiwania, Cunninghamia and Athrotaxis) with 16 species. Each genus contains only a few species or is monotypic with very limited relict distribution. With only one exception, Athrotaxis of Tasmania, genera of the family are restricted to the Northern Hemisphere. Three genera (Sequoia, Sequoiadendron and Taxodium) occurs in North America and remaining five in East Asia such as Japan, China and Taiwan. Most genera occur in mixed broad-leaved deciduous and/or evergreen forests of temperate to subtropical areas. In the present Japan, Cryptomeria japonica is the sole representative of the family. However, there are abundant fossil evidence that suggests the past presence of many other genera in Japan before some $1 \mathrm{Ma}$, when Metasequoia became extinct from Japan, to well back to the Cretaceous.

The close relationship of the Taxodiaceae to the Cupressaceae has been suggested by many earlier workers and is supported by recent molecular data. The rbcL gene analysis of the two families, for example, shows that the Cupressaceae are monophyletic, and are sister group to the Taxodiaceae (Chase et al., 1993). Emergence of the modern genera of Cupressaceae is believed to have occurred during the Cretaceous to Tertiary .

The Sciadopityaceae that were sometimes included in the Taxodiaceae are now believed to represent a monophyletic clade as implied from both morphological and molecular data. Fossils that can be assigned to Sciadopitys appear in the Late Cretaceous onward. Cones and vegetative parts of Sciadopitys have been found from the Upper Cretaceous of Hokkaido (Ohsawa et al., 1991).

\section{FOSSIL TAXODIACEAE}

There are few doubt for the Paleozoic Voltzialean origin of the Taxodiaceae as well as of other conifer families. The family is probably derived from the Pinaceae or from a complex ancestral to both by the Middle Jurassic. Middle Jurassic Pararaucaria from Argentine Patagonia represents such intermediate form (Stockey, 1977). One of the earliest fossil records that can be allied to the family is Middle Jurassic Elatides (Fig. 1). Fossils earlier than the Cretaceous generally cannot be assigned to any living genus, and are included to a fossil genus such as Geinitzia and Swedenborgia.

The oldest living genus known to date is probably Cunninghamia, which is morphologically most comparable to Geinitzia. The rbcL tree also reveals the basal position of Cunninghamia to the other extant genera of the family (e.g. Chase et al., 1993). The Taxodiaceae became most diversified in the Cretaceous when most extant genera other than Cryptomeria and Sequoiadendron were established. 


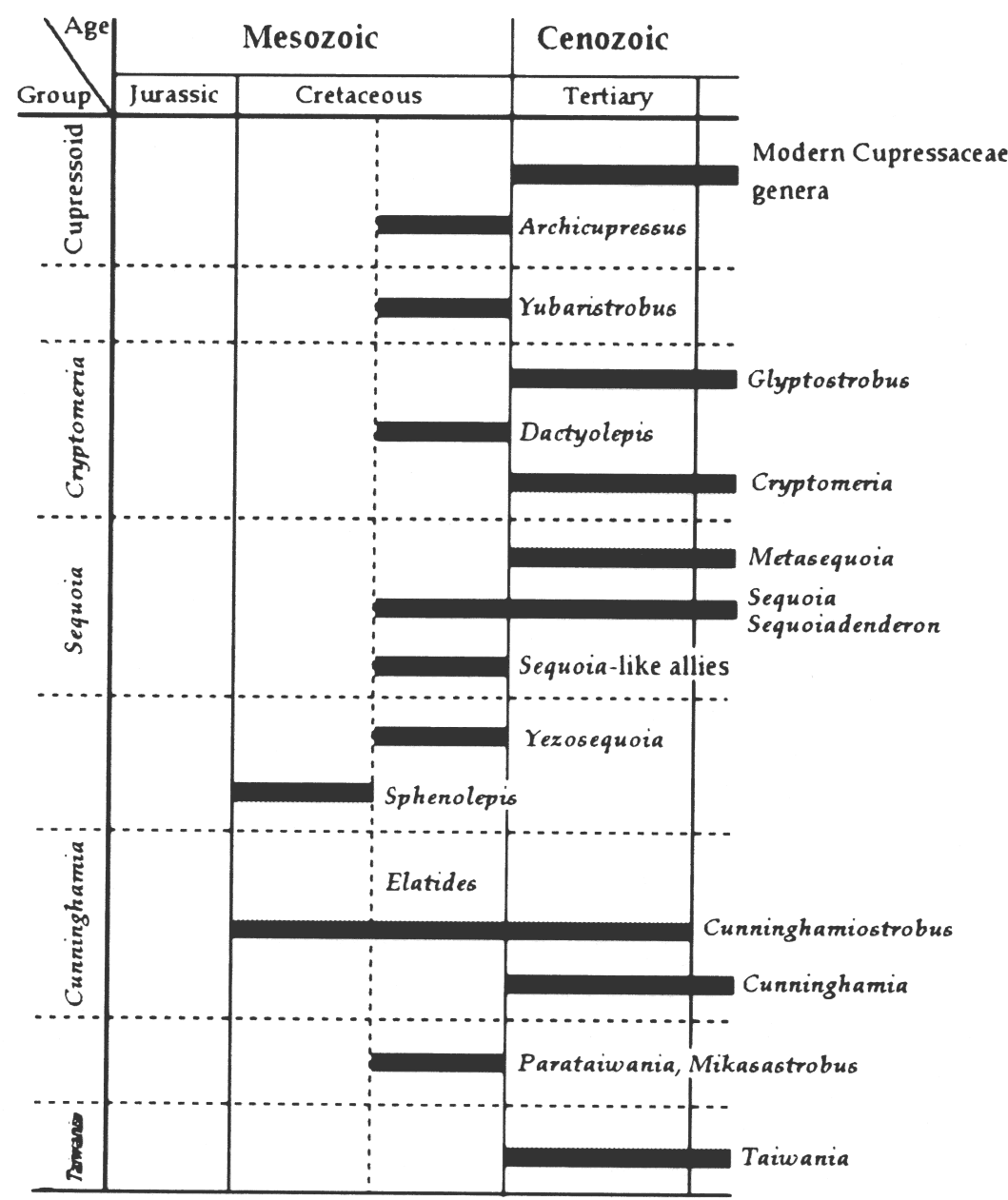

Fig. 1. Chronological distribution of taxodiaceous genera (redrawn from Ohsawa 1995).

During the Cretaceous, the Taxodiaceae were probably widespread worldwide including the Southern Hemisphere as, for example, represented by Austrosequoia from the Upper Cretaceous of Australia (Peters \& Christophel, 1978). A diverse array of taxodiaceous permineralized fossils including both modern and extinct genera are found from the Upper Cretaceous of Hokkaido, Japan (Ohsawa, 1994, 1995). By the end of the Cretaceous some members such as Metasequoia, Taxodium and Glyptostrobus achieved deciduousness in the middle- and high-latitudes forming mixed broadleaved deciduous and coniferous forests.

Excepting Athrotaxis, taxodiaceous genera have been a northern hemispheric family since the Tertiary (Florin, 1963). During the Paleocene and Eocene of globally warm period, the Taxodiaceae were widespread in the Northern Hemisphere. Even in the Arctic region, such deciduous genera as Metasequoia, Glyptostrobus and Taxodium are known to occur with occassional association of evergreen taxodiaceous genera as Taiwania and Sequoia. Also associated are Ginkgo, Thuja, Pseudolarix, Picea, Pinus and many broad-leaved deciduous trees. Remarkable evidence for the Eocene Arctic swamp forest consisting mainly of Glyptostrobus and Metasequoia was recently presented by Basinger et al. (1992).

Marked temperature decrease in the Late Eocene to earliest Oligocene resulted in the southward migration of northern deciduous broad-leaved forests to the mid-latitudes accompanying conifers such 


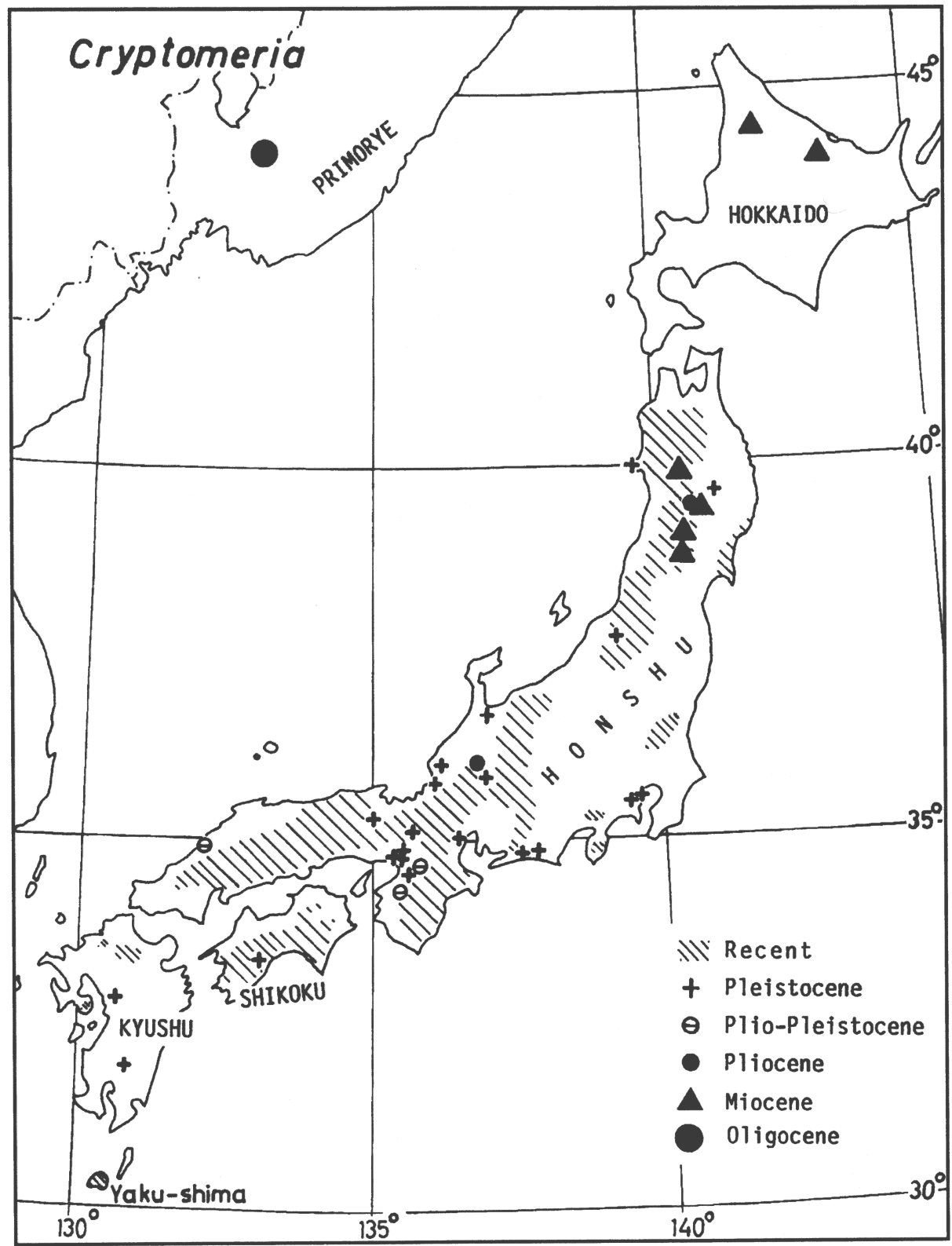

Fig. 2. Distribution of fossil and extant Cryptomeria in Japan and its adjacent areas.

as Metasequoia and Pinaceae genera. Subsequent climatic fluctuations since the Oligocene resulted in the restriction of distribution of many taxodiaceous genera in middle-latitudes.

As evident from the well-known work by Florin (1963) and from subsequent works, a more detailed phytogeographic history in the taxodiaceous genera can be added. Glyptostrobus and Sequoia show a wide geographic distribution in the Northern Hemisphere during the Tertiary. Taxodium also shows a wide distribution in the Northern Hemisphere during the Paleogene, but it disappeared from eastern Eurasia in the Neogene. Metasequoia shows a Tertiary distribution in North America and eastern Eurasia. The genus is also recorded from the Paleogene in Spitzbergen and England, but lacks its fossil records from European continent both in the Paleogene and Neogene. Fossil records of Cryptomeria and Taiwania, though not numerous, show their Eurasian distribution in the Tertiary. 

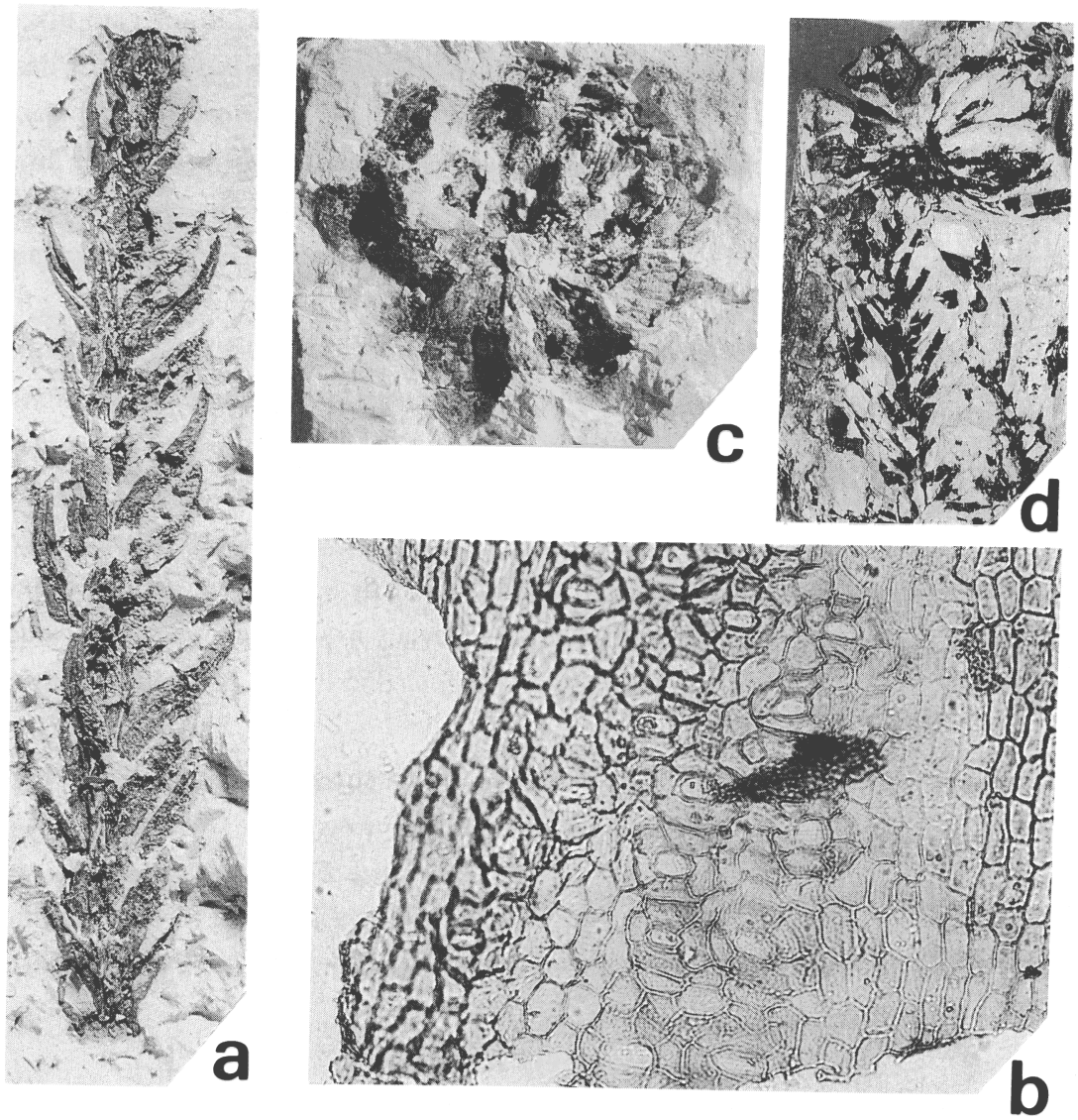

Fig. 3. Miocene Cryptomeria from Japan. a, b. leafy shoot $(\mathrm{a}, \times 2)$ an d cuticular features $(b, \times 300)$, Miyata Formation (Late Miocene), Akita Pref., NSM-PP6248a. c, cone, Miyata Formation (Late Miocene), NSM-PP 6277b, $\times 2$. d, leafy shoot with cone, Ohte Formation, (late Middle Mioceene), Hokkaido, NSM-PP 16721, $\times 1$.

\section{FOSSIL CRYPTOMERIA}

Cryptomeria is the only modern representative of the Taxodiaceae in Japan, being distributed in cooland warm-temperate forests from northeastern Honshu to Yaku-shima Island, Kyushu (Fig. 2). The genus is also believed to grow naturally in central to southern China (Tsui et al. 1978). Although fossil records are not numerous, Cryptomeria has a long history well back to the Tertiary as does the case of other taxodiaceous genera.

Sveshnikova (1967) reported the Late Cretaceous shoots from Yakutia, Russia under the name Cryptomeria subulata (Heer) Svesh., which was identified based mainly on their cuticular features. The Early Paleogene shoots with compressed cones from England, Cryptomeria sternbergi (Goeppert) Gardner (1883), have long been accepted as one of the unequivocal records of the genus. The former Russian fossils lack reproductive organs, and the latter Paleogene shoots are recently regarded as those of Glyptostrobus (Boulter and Kvacek 1989). Although more critical evaluation are required for these older records, the genus Cryptomeria did exist in the Miocene and Pliocene in Europe and East Asia, as evidenced by shoots and cones (Florin, 1963; Boulter, 1970; Uemura, 1981). 
The oldest Cryptomeria in East Asia was reported by Klimova (1975; see also discussion by Pimenov, 1984) from the Oligocene of Rettikhovka, Russia (Miocene in their original descriptions; see Uemura 1990). Cryptomeria miyataensis Huzioka et Uemura (1973) was described from the Late Miocene of Akita, Japan, on the basis of shoots and cones. Fossil forms identical or similar to $C$. miyataensis were subsequently found at many localities of Middle to Late Miocene and Pliocene floras in Honshu, Japan (Figs. 2, 3 ) . Quaternary occurrences of Cryptomeria were known at various localities in Japan (Miki, 1950).

In cases of fossil assemblages in Europe and at Rettikhovka, Cryptomeria occurs in association with other taxodiaceous genera such as Glyptostrobus, Metasequoia, Taxodium and Sequoia, together with other thermophilic trees (Boulter, 1970; Klimova, 1975). In contrast, Cryptomeria bearing assemblages in Japan, even of Miocene age, rarely contain other taxodiaceous genera and include many modernized temperate members of the Pinaceae, Betulaceae, Fagaceae, Rosaceae, Aceraceae and Rhododendraceae. Cryptomeria has probably adapted to a temperate forest since its first appearance in Japan. Similar evolutionary and adaptive tendency is also recognized in Sciadopitys, the genus which has a long geologic history since the Cretaceous and is now monotypic and endemic to Japan.

In the Pliocene to early Quaternary, Glyptostrobus, Metasequoia, Sequoia, Cunninghamia and Taiwania, together with other Tertiary elements like Ginkgo, Keteleeria, Pseudolarix, Comptonia, Liquidambar and so on, disappeared from Japan. After the disappearance of these genera, Cryptomeria has been a major component of the temperate forest in Japan. Overall humid climatic condition porbably is an essential physical factor to have allowed Cryptomeria persist in Japan.

\section{CONCLUDING REMARKS}

The Taxodiaceae took refuge in the areas where mesic temperate to subtropical forests have existed continuously since the Cretaceous. The very limited distributional pattern of each species probably resulted from a hierarchy between specific physiological preference, reproductive/ genetical peculiarities, and the local environmental change. Cryptomeria occurs in the mixed broad-leaved deciduous and/or evergreen forest zone, often forming the temperate coniferous forest. A wider range of temperature tolerance of Cryptomeria under the humid condition is one of the reasons for its survival in Japan. Well-preserved forest provides refuges for various organisms including the human being. The mesic to humid forests that have kept rare stands of many taxodiaceous trees, should be preserved without destroying its original diversity as a future heritage.

\section{REFERENCES}

Alvarez, L. W., Alvarez, W., Asaro, F. and Michel, H. V. 1980. Extraterrestrial cause for the Cretaceous/Tertiary extinction. Science 208: 1095-1108.

Basinger, J. F. et al. 1992. Early Tertiary vegetation of Arctic Canada and its relevance to paleoclimatic interpretation. In: Boulter, M. C. \& Fischer, H. C., eds., Cenozoic Plants and Climates of the Arctic. Springer- Verlag, Berlin.

Boulter, M. C. 1970. Cryptomeria - a significant component of the European Tertiary. Palaeont. Abh. B, 3: 279-286.

Boulter, M. C. \& Kvacek, Z. 1989. The Palaeocene flora of the Isle of Mull. Spec. Pap. Palaeont. 42: 1-149. 
Chase, M. W., et al. 1993. Phylogenetics of seed plants: an analysis of nucleotide sequences from the plastid gene rbcL. Ann. Missouri Bot. Gard. 80: 528-580.

Florin, R. 1963. The distribution of conifer and taxad genera in time and space. Acta Horti Bergiani 20: $121-324$.

Gardner, J. S. 1883-1886. A Monograph of the British Eocene Flora, 2. Palaeont. Soc., London. 159 pp.

Huzioka, K. \& Uemura, K. 1973. The Late Miocene Miyata flora of Akita Prefecture, Northeast Honshu, Japan. Bull. Natn. Sci. Mus., Tokyo 16: 661738.

Klimova, R. S. 1975. Miocene conifers from Rettikhovka. Fossil Flora of the Far East. Vladivostok, pp. 84-92 (in Russian).

Miki, S. 1950. Taxodiaceae of Japan, with special reference to its remains. J. Inst. Polytech., Osaka City Univ. 1: 63-77.

Ohsawa, T. 1994. Anatomy and relationships of the Cretaceous petrified cones of the Cupressaceae, Taxodiaceae and Sciadopityaceae. J. Plant Res. 107: 503-512.

Ohsawa, T. 1995. Affinities and Significance of Cretaceous Coniferous Cones from Hokkaido, Japan. D. Sc. Dissertation, Univ. Tokyo. 144 pp.

Ohsawa, T., Nishida, M. \& Nishida, H. 1991. Structure and affinities of petrified plants from the Cretaceous of Northern Japan and Saghalien, IX. Petrified cone of Sciadopitys from the Upper Cretaceous of Hokkaido. J. Phytogeogr. Taxon. 39: 97-105.

Pimenov, G. M. 1984. A new species of Cryptomeria from the Miocene of the Far East. Paleont. Zh. 1984: 80-85 (in Russian).

Tsui, H.-P., Cheng, W.-C., Fu, L.-K. \& Chao C.-S. 1978. Cryptomeria D. Don. In: Flora Reipubl. Popularis Sinicae 7: 293-299 (in Chinese).

Peters, M. D. \& Christophel, D. C. 1978. Austrosequoia wintonensis, a new taxodiaceous cone from Queensland, Australia. Canad. J. Bot. 56: 3119- 3128.

Stockey, R. A. 1977. Reproductive biology of Cerro Cuadrado (Jurassic) fossil conifers: Pararaucaria patagonica. Amer. J. Bot. 64: 733-744.

Sveshnikova, I. N. 1967. Late Cretaceous Coniferae from the U. S. S. R., I. Fossil Coniferae of the Viliuyian depression. Trud. Bot. Inst. An SSSR, Ser. 8, Paleobotanika 6: 177-203 (in Russian).

Uemura, K. 1990. Tertiary conifers in time and space. Japan. J. Hist. Bot. 5: $27-38$ (in Japanese). 


\section{西田治文, 植村和彦＼cjkstart植物地理学的にみたスギ科の歴史と針葉樹落葉／常緑広葉 樹混交林保護の重要性}

9 属の現生属があるスギ科はジュラ紀中期に出現した。白亜紀には世界中に広く分布しており, ジュラ紀 以来の絶滅属に加えスギ属とセコイアデンドロン属以外のすべての属が登場した。白亜紀の末期までに, メタセコイア，グリプトストローブス，タクソディウムなど落葉性の属が出現した。第三紀以降スギ科は ほとんど北半球の植物になり, 温暖な古第三紀には北極圈でも針葉樹広葉樹混交林が発達した。始新世後 期から漸新世の急激な気温低下に伴い, 北方落葉広葉樹林が南下し, メ夕セコイアやマツ科のような北方 性針葉樹が中緯度地域にまで分布を広げる一方，ヌマスギのような亜熱帯性の樹種は多くの地域で絶滅した。

日本最古のスギ属の記録は秋田の中新世後期からみつかった宮田スギで, 現在温帯林を形成しているブ ナ科、マツ科, カバノキ科, バラ科, カエデ科, ツツジ科などと共存している。鮮新世から第四紀の初期 までの間に, カニンガミア，グリプトストローブス，メタセコイア，セコイア，タイワンスギが日本から 絶滅した。同時にイチョウ，アブラスギ (ケテレーリア), イヌカラマツ (シュードラリックス), コンプ トニア, フウなど, 多くの第三紀要素が姿を消した。主な原因はさらに進んだ気温低下と冬季の乾燥だと いわれている。

スギ科は白亜紀以来，湿潤温帯林が継続して維持されてきた地域に残されてきた。スギ属は落葉または 常緑広葉樹との混交林に見られる。他の属に比べ広範囲の温度に適応していることがスギ属が日本に広く 残されてきた理由のひとつであろう。よく保存された森林は人間を含めた様々な生き物にとっての避難場 所である。湿潤温帯林をそれが本来持っている多様性を失うことなく将来にわたり保全して行くことが求 められて 